\title{
CONCEPTUAL IDEAS AND ORIENTATORS OF THE NOTHERN AMERICAN MODEL OF ADULT EDUCATION
}

\author{
Olena Terenko \\ Department of Foreign and Slavonic Philology \\ Sumy State Pedgogical University named after A. S. Makarenko \\ 87 Romenskaya str., Sumy, Ukraine, 40002 \\ eterenko@ukr.net
}

\begin{abstract}
The article deals with conceptual ideas and orientators of Northern American model of adult education. It is substantiated, that Nothern American model of adult education is based on the following philosophical directions: liberalism, progressivism, behaviorism, humanism, radicalism, constructivism. Liberalism has ancient roots and comes from the fact that since man is the real source of progress in society, it is necessary to ensure his rights and freedoms, providing equal access to education regardless of social status and well-being. The basic principle of liberal education is singled out, in particular, to develop a personality that is consonant with the purpose of a liberal education in ancient times - the education of citizens who can become active participants in a democratic society. It is proved that non-formal adult education should be continuous, focus on the development of intellectual abilities, be accessible to all sections of the population, and its content must meet their needs. It was found out that the historical roots of the philosophy of progressivism associated with progressive political movement in society and education. Its basis is the concept of interaction between education and society, empirical theory of education democratization of education. It was found out that behavioral direction, whose founder was John Watson, appeared in the USA in the early XX century. Based on the theory of Pavlov's conditioned reflexes, his supporters (J. Watson, B. Sninner E. Thorndike) examined personality as a set of behavioral responses to stimuli of the environment. It is identified that the purpose of adult education - behavior modification adult-oriented changes in humans. It was proved, that unlike behaviorists, representatives of humanistic direction (J. Brown, Johnson, Maslow, M. Knowles, K. Rogers, etc.) considered man independent, active, open to change and self-actualization person. It was stressed, that the founders of the radical trend, based on theories of anarchism, marxism, socialism, considering education in general and adult education, in particular, as an important mechanism to achieve radical changes in society. It updates the social role of non-formal adult education, because it requires critical thinking and personal participation in these changes. It was found out, that according to philosophy of constructivism person is unique in his/her vision of the world, beliefs, outlook because he/she is able to construct his/her personal understanding of reality. A teacher is not just a transmitter of knowledge,he/she serves as the consultant, moderator, facilitator. The analysis of scientific literature showed that adult education in the USA has evolved with the development of society, and has a long history and some traditions, mainly seen as informal adult education, aimed at self-improvement of adult to meet his/her educational needs; mechanism of civil society formation.
\end{abstract}

Keywords: adult education, conception, USA, liberalism, progressivism, behaviorism, humanism, radicalism, constructivism.

\section{Introduction}

The dynamism of world economic and social development, the processes of globalization and integration, the transition to an information society necessitate upgrading the education system, which is the methodological basis of the concept of «lifelong learning», which is regarded as an essential and mandatory component of the social model of modern society, as such, that is able to adequately respond to the challenges of modern society and provide professional human and social development throughout life. Adult education is one of the most important components of lifelong education.

The main factors of intensive development of adult education is the social and economic changes taking place in society. According to S. Merriam, namely the socio-cultural context that combines three dimensions: demographics, globalization of economy and technology, creating special interests and needs of adult persons, and educational opportunities available to them [1].

Statistical data show that in developed countries there is a trend of population aging. In 2014, the fate of the elderly increased $12 \%$ compared to $9 \%$ in 1994 and by 2050 is expected to increase to $21 \%$. In Sinai today the number of people after 65 years is $16.5 \%$. However, in 
modern adult appears more free time thanks to the latest technology. Therefore, US researchers stress the need to create an inclusive education model that takes into account the needs of adults of all ages [2].

The global economy is regarded by researchers as a megatrend of the XXI century, «has dramatic implications for adult education. This is due to a mismatch of knowledge and competence, a necessity to adequately use and performance of professional retraining, the transition to an economy in the service sector, changes in the labor force, and the transition to an information society, the achievements of scientific and technological progress, the emergence of new technologies.

A response of adult education in the sociocultural context of modern society is the integration and interpenetration of formal and informal education, which serves as a basis for building a society that learns.

Continuous education is understood today not only as a «learning in the length of life" (lifelong learning), but also as a «learning width of life" (lifewide learning), focusing on expanding the possibilities of education using both formal and informal education. In this context, non-formal adult education is regarded as an equivalent component of adult education as a social and cultural component that reflects the needs of adults in obtaining a variety of educational services. Therefore, to develop the theoretical foundations of formal education is important the pedagogical understanding of formal education as a component of adult education.

The aim of our research is to analyse conceptual ideas of northern American model of adult education.

\section{Materials and methods}

Structural and logical analysis of research on adult education allowed to state its multidisciplinary nature and identify key aspects of the research: philosophical, historical and pedagogical, psychological, social, educational, andragogical.

It is important to analyse philosophical approaches by S. Merriam, which influenced the development of adult education: liberalism, progressivism, behaviorism, humanism, radicalism constructivism [1].

Liberalism has ancient roots and comes from the fact that since man is the real source of progress in society, it is necessary to ensure his rights and freedoms, providing equal access to education regardless of social status and well-being. The basic principle of liberal education is to develop a personality that is consonant with the purpose of a liberal education in ancient times - the education of citizens who can become active participants in a democratic society.

According to E. Lindeman, the historical roots of the philosophy of progressivism associated with the progressive political movement in society and education. Its basis is the concept of interaction between education and society, empirical theory of education democratization of education. Since the intensive development of adult education falls on the progressivism heyday in the USA, it is not surprising that it had a significant influence. [3].

The research work of $\mathrm{N}$. Bidyuk justifies that the modern way of progressive education - a way of transforming the concept of «social reconstructivism», «public education» and «education for survival», which combines ideas, borrowed from educational, philosophical, anthropological, psychological and sociological theories. These concepts are directly related to non-formal education. On the concept of social reconstructivism informal adult education may be the mechanism that causes the corresponding «reconstruction» of society [5].

The main purpose of the concept of «education for survival», which was developed by D. Mann, was training for survival in conflicts and wars. Through its implementation in informal adult education the creation of educational programs on problems of suicide, drug abuse, alcoholism, etc was realized [6].

M. Knowles paid the special attention to the impact of the adult community on the community. Therefore, the concept of «public education» or «education community», which targeted improvements and solving community problems, formation of civil democratic society, occupy an appropriate place in informal adult education USA [7]. 
The behavioral direction appeared in the USA in the early XX century. Based on the theory of Pavlov's conditioned reflexes, it examined personality as a set of behavioral responses to stimuli of the environment.

Unlike behaviorists, representatives of humanistic direction considered man independent, active, open to change and self-actualization person. A. Maslow has identified the main characteristics of a person as particularly skilful perception of reality, that individual must take safely, recognizing him/herself, others and the environment, spontaneity, sensitivity to problems independent of the other, a constant desire to assess actions, compassion, search interpersonal relations, respect, ethical quality, friendly sense of humor, creative, striving for self-actualization, open to new experiences [8]. To reveal the inner potential of man - one of the main tasks of teachers humanists.

The founders of the radical trend, based on theories of anarchism, marxism, socialism, are considering education in general and adult education, in particular, as an important mechanism to achieve radical changes in society. It updates the social role of non-formal adult education, because it requires critical thinking and personal participation in these changes. A vivid representative of this philosophical direction is Paulo Freire, who believed that a radical transformation of society should involve wider sections of the population into education. In his works, «Education as the Practice of Freedom» and «Pedagogy of the Oppressed», he argued that the «banking concept» of adult education never offers to those who are studying the possibility of critical consideration of reality. Alternative to the «banking» concept of education P. Freire sees a concept «of the problem» that is regarded as humanistic and liberating practice, which states that «... the oppressed person has to fight for his/her release,» and «world is no longer something that should be described as misleading him/her, it becomes the object of converting human actions «. P. Freire invites people to explore and change society through acquisition of education [9].

Scientists are convinced that the "philosophy of adult education is the foundation of educational practice», to the structure that is able to combine individual components of adult education into a whole», identify the relationship of quantitative and qualitative changes [9].

Although most of the ideas of the XX century in the American educational philosophy were borrowed from large systems or schools of philosophy, the pedagogical theory of the beginning of XX century, under the influence of market demands, has formed a unique philosophy of pragmatism, along with behaviorism and social constructivism, which was typically American, and dictated the whole further development of philosophy of education in the USA.

In the XIX century the active thinking concerning educational experience and its justification started. The idea of non-formal adult education is justified in scientific studies of French philosopher J. Condorcet. He emphasized the importance and necessity of teaching people to a late age, using lectures, libraries, museums, etc.. To implement his ideas in practice, he managed to open the first night school for adults «New Institute for the formation of the human character.» In his autobiographical work «Going my way" he proves the importance of education for adults, reveals the essential features of their training and carefully describes his difficulties in organizing schools for adults [10].

P. Jarvis pays attention to the fact that the development of adult education in the United States and European countries was under the significant impact of the philosophical conception by N. Hrundtvih (1783-1872), especially under his conception of the Supreme People's school. The scientist considered adult education as «waking life», «spread of the light», «effect on the soul» and concerning higher public school, he wrote that it «should be a school for life ... must be historic and poetic ... should be a light to the people ... should be boarding school for adults» [11].

In the context of scientific understanding of the problems of adult education there is a significant psychological science research, revealing the specific psychology of adult learning: adult characteristics as a subject of study, the motivation of adult learning [11].

In this context of vital importance are studies by American scientists A. Maslow, which consider learning not as a «response to a stimulus or to meet the demands of new knowledge», but as a process of internal satisfaction «motives and impulses».

Referring to the definition of «needs»:it is interpreted as a state entity, which is characterized by dissatisfaction with the requirements of the body that is needed in life, and shouls be overcome; as the absence of a benefit; a need in anything that a person is going through and understands. 
P. Jarvis states that the need for knowledge inherent in every person, and the presence of fear of internal knowledge is not property, but a result of negative social experience. Without the need for knowledge a person can not understand the world in which he/she lives, adjust to it. Therefore, its taxonomy (scientist believes that the basic needs appropriately considered as taxonomy) needs knowledge that plays an important role [11].

We agree with P. Jarvis's thoughts on the importance of the need of knowledge, because it is a key feature of the adult education system, and even more important when it comes to informal adult education. Since the presence of such a need and desire to satisfy motivates adult independent and voluntary training. Motivation is considered as a specific emotional state that encourages an action to meet specific needs.

Scientific exploration shows that the problem of motivation of adult learning is of special importance. Thus, there are three fundamental ideas for motivating adult participation in education, with which we agree: motivation is internal to meet the diverse needs; motivation can be formed; motivation is related to the objectives, formulated and adopted by a man.

J. Rachal argues that motivation of adult learning has a different semantic focus: focus on the goal, focus on the process, focus on the subject [12].

T. Sticht classified motivational orientations of adults as the following: knowledge; achieve personal, social or religious purpose; take part in social activities; avoid anything; submit formal requirements [13].

At the beginning of the XXI century adult education is viewed as a branch that has history, social aim, organization, content, specialized programs, methods and teachers. The accent is paid to general cultural aims of adult education.

L. Bryson views adult eductation as all actions that have educational purpouse that are made by adults in everyday life with the aim of self-perfection. The scientist pays attention to the fact that additional aims of adult education are elimination of drawbacks of school education, organization of rest, professional training of adults [14].

$\mathrm{K}$. Werner views adult education as the activity between an agent of education and those who study with the aim of experience acquisition, which is necessary for taking part in the life of society. The researcher pays attention to acquisition of knowledge, skills that are necessary for adults for fulfillment of social roles of parents, citizens, workers, members of society [15].

According to $\mathrm{M}$. Thompson, adult education is viewed as a complex of organized educational processes that are independent of content, level and method, formal or another, that help to continue education that was obtained in an educational establishment and practical training due to which personality that is defined by society as adult develops his/her abilities, enriches his/her knowledge, perfects his/her technical and professional qualification or gets new orientation and changes his/her vision and behavior in dual perspective of the many-sided development and participation in the balanced, independent social, cultural and economic development [16].

S. Courtney states that adult education is represented in three meanings. According to the first meaning, adult education is a process of adult learning that embraces all actions of adults due to which they get new knowledge and skills. According to the second meaning adult education is a complex of organized types of adult activities that are made by different establishments and organisations. According to the third meaning, adult education combines processes and types of activities into the idea about the movement or branch of social practice. The scientist pays attention to the fact that adult education is many-sided, it reflects different aspects of the educational process that is why it can be viewed as a complex of establishments, specific type of relations, andragogics conception, professional or scientific discipline, basis for social movement, type of education with specific functions and aims [17].

$\mathrm{K}$. Houle views adult education as a process that has planning, made by personalities and agencies due to which adults individually or in groups help themselves or society. Thus, adult education has three components: transitional learning, client-oriented approach, influence of personal, cultural and social factors [18].

H. Long states that adult education combines all attempts of adults to become educated [19]. 


\section{Research results and their discussion}

Our research work gives a possibility to state that according to liberalism, non-formal adult education should be continuous, must focus on the development of intellectual abilities, be accessible to all sections of the population, and its content must meet their needs.

Supporters of progressivism in adult education stated that the purpose of adult education was considered to meet the educational needs of adults and insisted that adult education should be practice-oriented, based on the experience of adults and a teacher «is not a «sage « as in the liberal tradition, he/she becomes a «guide» that helps an adult to organize, encourage, implement and evaluate complex learning

According to behaviorism, the purpose of adult education is behavior modification, adult-oriented changes in humans.

We agree that andragogics is the science of adult education, the main provisions of which were founded by the American scientist M. Knowles, is a model of the humanistic approach to adult education, based on specific characteristics which investigated adult human subjects of the educational process, namely adult self- awareness as an independent individual; availability of life and professional experience, which becomes a source of education directly to person and his/her colleagues; availability of educational needs, aspiration through training to solve vital problems and achieve specific goals; the desire for self-education, self-education, self-development; desire for immediate implementation of acquired knowledge.

According to the philosophy of constructivism, a person is unique in his/her vision of the world, beliefs, outlook because he/she is able to construct his/her personal understanding of reality. A teacher is not just a transmitter of knowledge, he/she serves as a consultant, moderator, facilitator.

Our analysis of the scientific literature showed that adult education in the USA has evolved with the development of society, and has a long history and some traditions, mainly seen as informal adult education, aimed at self-improvement of an adult to meet his/her educational needs; mechanism of civil society formation.

We view adult edication as an organized educational process that helps an adult to aquire new knowledge, skills and competences; any person who has basic education can be included; it presupposes all types of education, with accreditation and without accreditation: formal, informal, non-formal; it comprises different types of learning organization - traditional and distant; can be organized not only in classes, but in workshops, libraries, churches, museums, at home; can be organized by different providers - private personalityies, volunteers, community.

\section{Conclusion}

The conducted research gives a possibility to state that:

1. The Nothern American model of adult education is based on the following philosophical directions: liberalism, progressivism, behaviorism, humanism, radicalism, constructivism.

2. Liberalism has ancient roots and comes from the fact that since man is the real source of progress in society, it is necessary to ensure his rights and freedoms, providing equal access to education regardless of social status and well-being. The basic principle of liberal education is to develop a personality that is consonant with the purpose of a liberal education in ancient times - the education of citizens who can become active participants in a democratic society.

3 . The historical roots of the philosophy of progressivism associated with progressive political movement in society and education. Its basis is the concept of interaction between education and society, empirical theory of education democratization of education.

4. The behavioral direction examined personality as a set of behavioral responses to stimuli of the environment. Hence the purpose of adult education - behavior modification adult-oriented changes in humans.

5. The founders of the radical trend, based on theories of anarchism, marxism, socialism, are considering education in general and adult education, in particular, as an important mechanism to achieve radical changes in society.

6. According to philosophy of constructivism, person is unique in his/her vision of the world, beliefs, outlook, because he/she is able to construct his/her personal understanding of reality. 
7. The analysis of the scientific literature showed that adult education in the USA has evolved with the development of society, and has a long history and some traditions, mainly seen as informal adult education aimed at self-improvement of an adult to meet his/her educational needs; mechanism of civil society formation.

Our future research work will be aimed at the analysis of procedural characteristics of adult education in the USA.

\section{References} Bass, 320

[1] Merriam, S. (2013). Adult Learning: Linking Theory and Practice. San Francisco: Jossey-

[2] Project: Education for Democratic Citizenship. Report on the Final Conference. Council for Cultural Cooperation (CDCC) DECS/EDU/CIT (2014). Strasbourg: Council of Europe, 42.

[3] Lindeman, E. (1989). The Meaning of Adult Education. Norman: University of Oklahoma Press, 143.

[4] Bergevin, P. (1997). Philosophy for Adult Education. New York: Seabury, 223.

[5] Bidyuk, N. (2009). Professional Teaching of Unemployed in the USA. Hmelnitsky, 542.

[6] Mann, D. (1997). Prior Learning Assessment: US Experience Facilitating Lifelong Learning. Vancouver: British Columbia Ministry of Advanced Education, 114.

[7] Knowles, M. (1977). A History of the Adult Education Movement in the United States. Malabar: Krieger Publishing, 426.

[8] Maslow, A. (1970). Motivation and Personality. New York: Harper \& Row, 362.

[9] Freire, P. (1987). A Pedagogy for Liberation: Dialogues on Transforming Education. South Hadley: Bergin \& Garvey Publishers, 208.

[10] Kondorse, J. (1936). Outlines of Historical Picture of Human Mind Progress. Moscow, 258.

[11] Jarvis, P. (2004). Adult Education and Lifelong Learning: Theory and Practice. London: RoutledgeFalmer, 320 .

[12] Rachal, J. R. (2002). Andragogy's Detectives: A Critique of the Present and a Proposal for the Future. Adult Education Quarterly, 52 (3), 210-227. doi: http://doi.org/10.1177/0741713602052003004

[13] Sticht, T. (2002). The Rise of the Adult Education and Literacy System in the United States: 1600-2000. The Annual Review of Adult Learning and Literacy, 3, 10-43.

[14] Bryson, L. (2006). Adult Education. New York: American Book Company, 208.

[15] Werner, K. (2009). Adult Education Theory and Method: A Conceptual Scheme for the Identification and Classification of Processes. Washington: Adult Education Association of the USA, 342. $20,51-71$.

[16] Thompson, M. (2011). Adult Education in a Technological Society. Journal of Lifelong Learning,

[17] Courtney, S. (2015). Defining Adult and Continuing Education. San Francisco: Jossey-Bass, 200.

[18] Houle, C. (2016). The Design of Education. San Francisco: Jossey-Bass, 282.

[19] Long, H. (2018). Theoretical and Practical Implications of Selected Paradigms of Selfdirected Learning. Norman: Public Managers Center at University of Oklahoma, 400. 